\title{
SOME NEW AND OTHER NOTEWORTHY PLANTS OF THE NORTHWEST.
}

J. M. GREE N MAN .

Sprefa deNSIFlora Nutt. in Torr. and Gray Fl. I: 4 I 4.

S. betulafolia Pall. var. rosea Gray, Proc. Am. Acad. 8:381. I872.

S. lucida Dougl. var. rosea Greene, Pittonia 2:221, 1892 .

S. arbuscula Greene, Erythea $3: 63$. 1895 .

This showy alpine plant, which has recently attracted considerable attention, was originally collected and characterized as Spirea densiflora by Nuttall, whose type specimen is preserved in the Gray Herbarium. The first publication of the above name, however, appears in Torr. \& Gray's Flora I : 4I4, where the plant is briefly described as a roseate-flowered form of $S$. betulafolia, and the name $S$. densiflora Nutt. MSS. cited as a synonym. In Proc. Am. Acad 8:38 I Dr. Gray established a variety rosea of S. betulafolia Pall., based upon Hall's no. I 24, but this plant is exactly the same in every regard as Nuttall's S. densifora, and in no respect more perfectly characterized. In 1892 Prof. Greene (Pittonia 2:22 I) transferred the variety to S. lucida a distinct the same time suggesting the probability of its being as S. arbuscula. material confirms. The examination of a considerable amount of specific rank; and Pall, may be seen and that it is quite distinct from S. betulifolia of the latter seen by a comparison with the excellent illustration seems no rear species in Pall. Fl. Ross. 1:33. pl. 16, but there although bron for discarding Nuttall's name $S$. densiflora, which possibility of $S$ was intelligibly characterized in 1844 . The as suggested $S$. pyramidata being the same as S. densiflora Nutt., the question by Prof. Greene in Pittonia $2: 221$, is quite out of foliar chara. The two plants are very different in inflorescence, 18987 characters, and color of the flowers. 
A very excellent illustration of $S$. densiflora Nutt. may be found in Gard. \&o For. 10: fig.53. It may be said, however, that the leaves are somewhat variable as to the serration, being crenate-serrate to rather sharply serrate. To this species may be referred: CALIForniA, Brewer 1777, I932, 2090: Bolander I3I; Lemmon, from Sierra Co. (in I 874); Torrey I3 1 ; Hansen 235; J. D. Hooker and A. Gray, Hermits Valley: Oregon, Hall I25; Cusick 122, in part, as to small leaved, purple flowered, densely corymbose form : WasHIsGToN, Henderson 245 ; E. C. Smith 354; O. D. Allen 57, 290; Piper 1993; Wyoming, Nelson 94I: BRitish Columbia, mountain slopes in the Selkirk range, Macoun. Probably also extending northward to Alaska.

In the second century of Mr. O. D. Allen's distribution of Washington plants, no. I 25 was distributed as Pyrus sambucifolia Cham. \& Schlecht. It should be referred rather to Pyrus occidentalis Watson.

Polemonium bicolor.-A low cespitose perennial: the stems covered below by persistent attenuate sheaths, which remain behind as the remnants of the earlier leaves: flowering stems 6 to I $8^{\mathrm{cm}}$ high, glandular pubescent with a few long pilose hairs intermixed, I-3-leaved : the basal leaves with somewhat dilated or clasping petioles; the leaflets $2 \mathrm{I}$ to $3 \mathrm{I}$ in number, obovaterotund to oblanceolate, 4 to $6^{\mathrm{mm}}$ long, 2 to $4^{\mathrm{mm}}$ broad, glandular pubescent with a strongly glandular-ciliate margin, more or less crowded or sometimes imbricated: inflorescence cymulose: peduncles $\mathrm{I}^{\mathrm{cm}}$ or less in length, glandular-pubescent: calyx 6 to $8^{\mathrm{mm}}$ long, veiny, glandular-pubescent with long spreading pilose hairs intermixed; lobes oblong linear, obtuse, corolla with a deep yellow throat and a dark purple to whitish limb, narrowly funnelform, 12 to $16^{\mathrm{mm}}$ long; tube slightly ampliated above, somewhat exceeding the calyx; the obovate lobes sto $^{\text {to }}$ $7^{\mathrm{mm}}$ long: stamens shorter than the corolla; filaments not appendaged at their pubescent bases: style slender, filiform. nearly as long as the corolla: capsule glabrous, $4^{\mathrm{mm}}$ long, of about one-half as long as the more or less persistent calyx; seeds angular, $\mathrm{I} .5$ to $2^{\mathrm{mm}}$ long.-Collected by O. D. Allen on Mit. Rainier, Washington, altitude $2460^{\mathrm{m}}$, August 8,1897 , no. 294-

To this species may be referred specimens collected by Suksdorf on Mtt Adams (Mt. Paddo), Washington, altitude $2150-2460^{\mathrm{m}}$, August 9,1882, 00 . 
79; Howell, Mt. Adams (in 1882); Henderson 241 I, East Mt. Adams ; E. C. Smith 780 , Mt. Rainier, altitude $2770^{\mathrm{m}}$, August 1890 ; O. D. Allen 62, Mt. Rainier; Piper 2129, Mt. Rainier, altitude $2770^{\mathrm{m}}$, August 1895 .

A species well marked by its cespitose habit and glandular character, and especially by the long narrowly funnelform corolla, quite distinct from P. humile Willd. var. pulchellum Gray, with which it has been confused. The most nearly related species is the P. Richardsonii Graham, Bot. Mag. pl. 2800. A part of the type material of the latter species is in the Gray Herbarium, and it is a plant with larger nearly glabrous leaflets and somewhat broader calyx-lobes and less tubular corolla.

Polemonium viscosum Nutt. var. pilosum.-Stems 6 to $10^{\mathrm{cm}}$ high; the entire plant covered with a spreading pilose pubescence intermixed with short glandular viscid hairs: leaflets usually less crowded or imbricated than in the type of the species: the calyx-lobes somewhat variable, oblong-ovate to distinctly oblong, obtuse or rounded at the apex: corolla white or pale blue with a yellowish center, $\mathrm{I}^{\mathrm{cm}}$ or less long.-Collected by O. D. Allen in clefts of rocks on Goat mountain, Washington, altitude $\mathrm{I} 540^{\mathrm{m}}$, July 6 , I 896 , no. 261 .

Somewhat intermediate between the above variety and the species proper are specimens from Lassen's Peak, California, collected by J. G. Lemmon in 1875 (nos. 20, 960), referred by Dr. Gray to $P$. humile Willd. var. pulchellum Gray. Mr. Lemmon's specimens have the spreading pilose pubescent character of the variety, but to a much less extent, particularly on the calyx. There is also in the Gray Herbarium a specimen from Lassen's Peak, collected by Mrs. Austin in I879, likewise referred to $P$. humile Willd. var. pulchellum Gray, which corresponds very accurately to Nuttall's type of $P$.

Veronica Allenii.-Perennial: stems. 6 to $8^{\mathrm{cm}}$ high, nearly glabrous below, pubescent above: the lower leaves much reduced, the upper sessile, thickish, oblong or oblong-ovate, Io to $14^{\mathrm{mm}}$ long, 4 to $9^{\mathrm{mm}}$ broad, obtuse, glabrous or with a few scattered hairs on the midrib and margin: inflorescence in a terminal raceme, glandular-pubescent: peduncles 2 to $5^{\mathrm{mm}}$ in length, often exceeding the herbaceous glandular bracts: calyx unequally 5-parted; divisions oblong or oblong-ovate, obtuse or theunded at the apex, covered on the outer surface and along the margin with long slender glandular hairs: corolla 6 to $7^{\mathrm{mm}}$ 
in diameter, white or white with a slightly purplish puberulent throat; the upper lobe sub-rhombic, conspicuously emarginate, the lateral lobes ovate or ovate-rhombic, somewhat larger than the lower lobe: stamens exserted: ovary closely covered above with short glandular hairs; style exserted, about $5^{\mathrm{mm}}$ in length: fruit not seen.-Collected by O. D. Allen along Paradise river on Mt. Rainier, altitude $1700^{\mathrm{m}}$, August 20, 1897, no. $95 a$.

A species habitally like $V$. Cusickii Gray, but differing by the somewhat smaller flowers, the white corolla, and less exserted stamens and style.

Castilleia oreopola.-Simple or many stemmed from a perennial base: stems erect, I. 5 to $3^{\mathrm{dm}}$ high, somewhat furrowed by the inconspicuous decurrence of the leaves, below glabrous or nearly so, covered above with a scattered spreading soft pubescence : leaves sessile, oblong-lanceolate, 2 to $4^{\mathrm{cm}}$ long, 5 to $10^{\mathrm{mm}}$ broad, with one or two pairs of divaricately spreading linearattenuate lobes, 3-nerved, glabrous or the uppermost covered with a soft spreading pubescence especially on the nerves and margins; the lower leaves much reduced, usually entire: inflorescence terminating the stem in a short close subcapitate raceme, later becoming elongated : bracts 3 -cleft to the middle, the lobes as well as the calyx of a "deep rose-purple:" calyx $18^{\mathrm{mm}}$ long, about equally divided anteriorly and posteriorly for one-half its entire length; lobes oblong-linear, obtusish: corolla $2^{\mathrm{cm}}$ long; the narrow exserted galea green on the back with thin subscarious deep rose-purple margins; lip included, rather deeply and subequally 3 -lobed: mature capsule oblong, about $\mathrm{I}^{\mathrm{cm}}$ long, glabrous.-Collected by W. N. Suksdorf in damp ground, on Mt. Adams (Mt. Paddo), Washington, altitude 1840 to $2150^{\mathrm{m}}$, August and September, I89I, no. 2046, distributed as Castilleia miniata Dougl. var. alpina Suksdorf; O. D. Allen, Mt. Rainier,

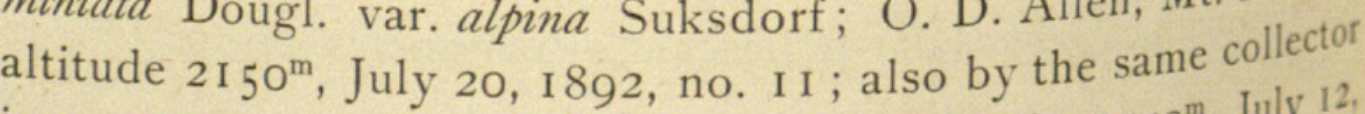
in open ground on Goat mountain, altitude $1540^{\mathrm{m}}$, July 12 , I895, no. I34, the latter distributed as C. alpina Greenman, n. sp. 
On account of the previous use of the name alpina in this genus by Porter it seems advisable to publish the species under the above name in order to aroid further and unnecessary change. A species readily recognized by the deep purple or almost magenta color of the bracts and flowers, and distinguished from $C$. parviflora Bong., its nearest ally, by the larger flowers, longer calyx, usually 3 -cleft leaves, narrower and 3 -lobed instead of 5 -lobed bracts.

For some time it has been evident that the many forms under Castilleia pallida of American authors have constituted an extremely composite group. The recent activity among collectors of the northwest has brought to hand a considerable amount of complete material. A study of the group in the light of more copious material and recently collected specimens has made it possible to separate out as distinct species or varieties certain so-called forms hitherto included under $C$. pallida.

Castilleia pallida HBK. Nov. Gen. \& Spec. 2: 33I. I8I7; Kunth, Syn. Pl. Equin. 2: I oo. I823; Gray, Syn. Fl. 2: 297. Bartsia pallida L. Spec. 2 : 602 (Gmel. Fl. Siber. 3: 201. pl. 42). -Perennial: stems $\mathrm{I} .5$ to $3^{\mathrm{dm}}$ or more high, rather sparingly pubescent below, covered above, especially in the inflorescence, with long somewhat matted hairs: leaves lance-attenuate, mostly entire, the upper usually broader and more or less lobed, soft-puberulent on either surface: calyx about $2^{\mathrm{cm}}$ long, cleft about equally before and behind, the lateral divisions again more or less 2-cleft; lobes linear-lanceolate, obtusish: corolla slightly exceeding the calyx; galea about $7^{\mathrm{mm}}$ long, nearly or quite twice exceeding the rather prominently 3 -lobed lip.Originally collected in Siberia.

There is in the Gray Herbarium a specimen, from the Herbarium of the This plant has Petersburg, collected by Chamisso on the island of Chamisso. int has been taken as typical of the species.

Castilleia PALlida HBK. var. lutescens. - Stems 3 to $5 \cdot 5^{\mathrm{dm}}$ leaves linear stouter than the species, usually branched above: the upper linear-lanceolate to oblong-lanceolate, the lower entire, lateral uper often trifid or sometimes even with a second pair of ateral lobes, scabrous especially on the upper surface: lip. 
slightly shorter in proportion to the length of the galea than in the species proper.-Suksdorf 424 , prairies, Spokane co., Washington, June I 884 ; C. V. Piper I667, Pullman, Washington, June 26, I893; Rev. H. H. Spaulding, Clear Water, Oregon; F. Lamson Scribner 197, near Jefferson City, Montana, June 27, 1883; Messrs. Sandberg, MacDougal, and Heller 450, Latah co., Idaho, June 20, I892; Macoun 5, Sproat, B. C., June 24, I890.

CAstilleia pallida HBK. var. camporum.- Stems usually several rising from a perennial base, I. 5 to $4^{\mathrm{dm}}$ high, more or less covered with a spreading pilose pubescence: leaves narrowly oblong-lanceolate, the lower mostly entire, the upper irregularly laciniately $3-7$-lobed with rather narrow ascending lobes, pubescent upon either surface: inflorescence greenish yellow or tinged with red, later becoming much elongated: calyx 2 to $2.5^{\mathrm{cm}}$ long; lateral divisions again shortly 2 -lobed (rarely entire), obtuse or even rounded at the apex; lip one-half to two-thirds as long as the galea.-Suksdorf 423 , low prairies, Spokane co. Washington, June I884; Piper 2514, Powder river mountains, Oregon, August i 896: Cusick 840, Union co., Oregon, I879, in the Gray Herbarium under "Orthocarpus castilleioides;" also a duplicate specimen under "C. pallida fere vera." A specimen from Henderson, Lincoln co., Washington, 1892, no. 2266, seems to have its affinity here, as does also an imperfect specimen from the Herb. Geol. and Nat. Hist. Survey of Canada, collected by McEvoy, along Meadow creek, B. C., June 24, I890, no. 2. In the latter specimen, however, the calyx is unusually long, being fully $3^{\mathrm{cm}}$ in length.

The above variety appears to be intermediate between the species propet and the var. occidentalis, having more divided leaves and more spreading pubescence than the species, but approaching the var. occidentalis as shown by specimens collected by Scribner in the Little Belt mountains, Montana. no. I98, and also specimens obtained by Aven Nelson at Dome lake, Wyouling, no. 2435 .

\section{Castilleia pallescens.}

Orthocarpus pallescens Gray, Syn. F1. 2 : 299.

O. Parryi Gray, Am. Nat. $8: 2$ I $_{4}$. 
The examination of a considerable amount of material shows that this species, hitherto somewhat doubtfully referred to Orthocarpus, has its affinity rather with the genus Castilleia. Notwithstanding the rather prominent lower lip and the short, broad galea, yet the very slight saccate character of the lip, and the calyx cut about equally before and behind with the lateral lobes shortly 2-cleft at the apex, combined with the perennial habit, all indicate its relation to Castilleia, and to the C.pallida group. In addition to the characters already given the following supplementary description may be appended. Stems 1.5 to $3^{\mathrm{dm}}$ high, usually several rising from a woody perennial base, simple or sparingly branched above, cinereous-puberulent often with spreading pilose hairs, especially below.

Nuttall's specimen from the Rocky mountains; Parry 218, Northwestern Wyoming Expedition, I873; Cusick 93, Union, Oregon, 1875; Canby, near Blackfoot City, Montana, July II, $188_{3}$, no. 26I in part (as to specimens distributed under Orthocarpus pallescens Gray, not as to specimen distributed as 0 . pilosus Watson); Macoun, Kamloops, B. C., June I3, I889; here also may be referred as more pubescent forms, Henderson 2267, 2268, 2269, Washington; and a plant of Dr. Lyall's Oregon Boundary Collection of I860 originally distributed as "Castilleja pallida var.?"

Castilleia Cusickii.-Stems several from a procumbent base, 4 to $\overline{4} .5^{\mathrm{dm}}$ high, simple or branched above, green or greenish purple, covered with a short spreading or slightly reflexed cinerous pubescence: leaves scattered, sessile, 3-nerved, hirtellouspuberulent upon either surface, the lower leaves linear to linearlanceolate, acute, 2 to $3^{\mathrm{cm}}$ long, about $3^{\mathrm{mm}}$ wide, the upper lamewhat larger, 3.5 to $4.5^{\mathrm{cm}}$ long, 3 to $5^{\mathrm{mm}}$ broad, and usually laciniately lobed with one or two pairs of slender divaricately spreading lobes on either side, the veins beneath prominent: racemes rather dense, 3 to $\mathrm{I}^{\mathrm{cm}}$ long, $\mathrm{I} .5^{\mathrm{cm}}$ or less broad; rhachis covered with a long flaccid sublanate pubescence: bracts about equaling or slightly exceeding the flowers, oblong, obtuse, or rounded at the apex, usually undivided and entire, strongly cilireticulate-veine base, distinctly 3 -nerved, and rather strongly eticulate-veined, 23 to $28^{\mathrm{mm}}$ long, abcut $7^{\mathrm{mm}}$ broad: flowers 2 
to $2.5^{\mathrm{cm}}$ long: calyx pubescent on the outer surface, nearly equally divided anteriorly and posteriorly; the lateral divisions linear-oblong, 2 -dentate or shallowly 2 -lobed at the apex, prominently 2 -veined even to the base of the calyx: corolla 2 to $2.5^{\text {m }}$ long, slightly exceeding the calyx, but scarcely twice the length of the rather prominent but not saccate 3-lobed lip: only the two anterior stamens protruding beyond the lip: style somewhat exceeding the galea, shallowly 2-lobed: capsule oblong, about $\mathrm{I}^{\mathrm{cm}}$ long, $4^{\mathrm{mm}}$ broad, glabrous.-Collected by William C. Cusick in Sumter valley, Blue mountains, Oregon, July 6, 1897. no. I700. The flowers are said by the collector to be "pale yellow rarely tinged with red."

A species related to C.pallida $\mathrm{HBK}$., from which it is distinguished by the foliar characters, pubescence of the stem and leaves, and the long, slender inflorescence.

Castilleia levisecta. - Many stemmed from a perennial base: stems -1.5 to $3^{\mathrm{dm}}$ high, usually unbranched above, covered with a soft more or less spreading unequal pilose pubescence: leaves oblong-lanceolate, 2.5 to $4^{\mathrm{cm}}$ long, 5 to $\mathrm{I}^{\mathrm{mm}}$ broad, $3-5_{\text {-nerved, }}$ pubescent upon either surface, often bearing rather long pilose hairs on the veins beneath: the lower somewhat narrower and often entire; the upper more dilated and shallowly lobed toward the apex with one to three pairs of lobes on either side: inflorescence rather densely spicate or subracemose: bracts yellow, rather broad, subdigitately lobed at the apex: calyx 15 to $18^{80}$ long, nearly equally cut before and behind, externally pubescent; the lateral lobes again rather deeply 2-lobed, obtuse or rounded at the apex: corolla $2^{\mathrm{cm}}$ or more long; galea 6 to $9^{\mathrm{m}}$ long; the lip one-third as long as the galea, shortly and obtusely 3-lobed: capsule glabrous, 8 to $\mathrm{IO}^{\mathrm{cm}}$ long, usually covered by the persistent pubescent calyx.-Howell 279, Mill plain, Washington, I880, O. D. Allen 83, Roy, Washington, May 19, 1889: F. Binns, in open woods and hills, Pt. Ludlow, Washington, June I 5, I890; Macoun 7I5, vicinity of Victoria, Vancouver Island, B. C., May I6, I893. 
A species hitherto confused with C. pallida $\mathrm{HBK}$., but differing materially in the foliage, and in the character of the lip of the corolla.

Castilleia cervina.-Cinereous-puberulent throughout: stems simple, $6^{\mathrm{dm}}$ or more high, somewhat striate above: leaves usually deeply $3(-5)$-parted, with the lateral divisions linear-attenuate and divaricately spreading: the lower flowers of the spicate inflorescence short-pedicellate: bracts laciniately 3-5lobed, lobes ascending, these as well as the calyx and corolla, in the dried state, tipped with yellow: calyx 1.5 to $2^{\mathrm{cm}}$ long, more deeply cut before than behind; the lateral lobes again shortly and acutely bilobed: corolla 2 to $2.5^{\mathrm{cm}}$ long; galea about $6^{\mathrm{mm}}$ long; the lip nearly or quite one-half as long as the galea, lobes conspicuous and subequal: stamens and stigma exserted.-Collected by Dawson on dry ground, Lower Arrow lake, B. C., June 17, 1889; and in the same locality by Macoun, June 5, I 890 , no. II.

Most nearly related to C. breviflora Gray, from which it is readily distinguished by the taller habit and the pubescence of the inflorescence.

Nemacladus Rigidus Curran. This interesting little plant, hitherto known only from the type locality, was collected by Jr. Cusick on the hillsides of the Malheur, Oregon, June I897, no, 1625 .

Gray Herbarium of Harvard University. 


\section{$2 \mathrm{BHL}$ Biodiversity Heritage Library}

Greenman, J. M. 1898. "Some New and Other Noteworthy Plants of the Northwest." Botanical gazette 25(4), 261-269. https://doi.org/10.1086/327668.

View This Item Online: $\underline{\text { https://www.biodiversitylibrary.org/item/94870 }}$

DOI: https://doi.org/10.1086/327668

Permalink: https://www.biodiversitylibrary.org/partpdf/222864

\section{Holding Institution}

Missouri Botanical Garden, Peter H. Raven Library

\section{Sponsored by}

Missouri Botanical Garden

\section{Copyright \& Reuse}

Copyright Status: Public domain. The BHL considers that this work is no longer under copyright protection.

This document was created from content at the Biodiversity Heritage Library, the world's largest open access digital library for biodiversity literature and archives. Visit BHL at https://www.biodiversitylibrary.org. 